\title{
STUDY OF ANTI-INFLAMMATORY EFFECT OF CONCENTRATED JUICE AND GRANULES FROM VACCINIUM OXYCOCCOS FRUITS ON THE MODEL OF BACTERIAL CYSTITIS IN RATS
}

\author{
Kateryna Yatsyuk \\ Department of Organization and Economics of Pharmacy and Drug Technology \\ yatsina_katya@i.ua \\ Mariana Fedorovska \\ Department of Organization and Economics of Pharmacy and Drug Technology ${ }^{l}$ \\ maryana@fedorovska.com \\ Olga Antymis \\ Department of Human Anatomy \\ antimis2012@gmail.com \\ ${ }^{1}$ Ivano-Frankivsk National Medical University \\ 2 Halytska str., Ivano-Frankivsk, Ukraine, 76018
}

\begin{abstract}
The fruits of marsh cranberries due to the content of phenolic compounds, in particular proanthocyanidins, are effective in the prevention and treatment of cystitis [1].

The aim of the research was to study the anti-inflammatory properties of condensed juice of Vaccinium oxycoccos fruits and granules «Cranberry» in a model of acute bacterial cystitis in rats.

Materials and methods. The anti-inflammatory properties of condensed juice from Vaccinium oxycoccos fruits and granules «Cranberry» were studied in a model of acute bacterial cystitis in rats, which was caused by three daily transurethral injection into the bladder of $0.3 \mathrm{ml}$ of E. coli strain at a concentration of $10^{6} \mathrm{CFU} / \mathrm{ml}$. «Canefron ${ }^{\circledR} \mathrm{H}$ » was used as a reference drug. Tissues were studied histologically by assessing the structure of the bladder wall and the condition of blood vessels.

Results. Infection of animals with $E$. coli resulted in a significant increase in the desquamation of the transitional epithelium, edematous changes and narrowing of blood vessels in the tissues of the bladder wall. During treatment with the drug «Canefron ${ }^{\circledR} \mathrm{N} »$ there was a decrease in cell infiltration and desquamation of cells, dilation of blood vessels. When animals used condensed juice from Vaccinium oxycoccos fruits and granules «Cranberry» in the histological picture of the walls of the bladder there was a decrease in desquamation, edema and cellular infiltration, the lumen of blood vessels was approaching normal.

Conclusions. The use of condensed juice from Vaccinium oxycoccos fruits and granules «Cranberry» was accompanied by a positive effect on the tissues of the walls and blood vessels of the bladder of rats (there was a decrease in desquamation of the superficial layers of the transitional epithelium and normalization of the histological picture of vascular entanglement, that was not inferior to the comparison drug «Canefron ${ }^{\circledR} \mathrm{N} »$.
\end{abstract}

Keywords: Vaccinium oxycoccos, condensed juice, granules, acute bacterial cystitis, anti-inflammatory properties.

DOI: $10.21303 / 2504-5679.2020 .001505$

\section{Introduction}

Urinary tract infections (UTI) are among the most common infectious diseases in the world, often occurring in relatively healthy people [2]. At the same time, there is a high rate of recurrence - in 30-40\% of patients who underwent UTI [3]. The main pathogens of UTI in $80 \%$ of cases are Escherichia coli and in $15 \%$ of cases Proteus spp., Pseudomonas aeruginosa, Staphylococcus aureus, S. typhymurium, Enterococcus faecalis [4-10]. The basic drugs for the treatment of patients with UTI are antibiotics and uroantiseptics (derivatives of 8-oxyquinoline, 5-nitrofuran, etc.) $[11,12]$. For the prevention of UTI, the European Association of Urologists recommends the daily use of Vaccinium oxycoccos with a content of proanthocyanidin A 36-72 mg per day [13-15]. To ensure a daily therapeutic dose, it is necessary to consume from 0.5 liters of fresh juice per day, 
which causes some difficulties (unpleasant organoleptic properties, irritation of the gastrointestinal tract, the dependence of raw materials on the season) [16].

Given the above, it is important to develop dosage forms from the juice of Vaccinium oxycoccos fruits, such as condensed juice and granules based on it. These funds have a number of advantages, namely: they are characterized by a concentrated content of proanthocyanidins, easy to use, available regardless of the season of harvesting.

The aim of the research was to determine the anti-inflammatory properties of condensed juice from Vaccinium oxycoccos fruits and granules "Cranberry» in a model of acute bacterial cystitis in rats.

\section{Materials and methods}

An experiment to determine the anti-inflammatory properties of condensed juice and granules «Cranberry» [17-19] was conducted in May 2018 on the basis of the laboratory of practical pharmacy No. 3 of the Department of Organization and Economics of Pharmacy and Drug Technology and scientific laboratory of morphological analysis of Ivano-Frankivsk National University. All studies were conducted in accordance with EU Directive 2010/63/EU on the protection of animals used for scientific purposes [20], complied with the recommendations of ARRIVE [21], as confirmed by the expert opinion on ethics of Ivano-Frankivsk National Medical University on ethical principles in performance of candidate dissertations (protocol No. 113/20 from 12.03.2020).

The experiment was performed on 30 outbred white male rats weighing 200-250 g, which were divided into 5 groups of 6 animals [22]. The first group of animals (healthy rats) was used to determine the histological structure of the walls and blood vessels of the bladder in normal. Other experimental animals simulated acute bacterial inflammation of the bladder by three daily transurethral injections into the bladder of $0.3 \mathrm{ml}$ of suspension of uropathogenic clinical strain of E. coli (isolate from a patient with recurrent cystitis) at a concentration of $10^{6} \mathrm{CFU} / \mathrm{ml}$. The process of infection of the rat with the pathogen is shown in Fig. 1. The second group of animals was left untreated. The third group was treated for acute cystitis by daily oral administration of the drug «Canefron ${ }^{\circledR} \mathrm{N}$ », which has proven effectiveness in the treatment of infectious diseases of the urinary tract in the form of drops at the rate of 2 drops per day [23]. In the fourth group of animals, treatment was performed with condensed juice of Vaccinium oxycoccos fruit, administered to rats orally at the rate of $0.01 \mathrm{~g}$ per day. The fifth group was treated with «Cranberry» granules, administered orally to animals at a rate of $0.06 \mathrm{~g}$ per day. Doses of the studied drugs were calculated taking into account the quantitative content of proanthocyanidins [18, 19]. Animals before and after the experiment were kept in a specially equipped room, which is well ventilated, well lit, at a temperature of $+20{ }^{\circ} \mathrm{C}-+22{ }^{\circ} \mathrm{C}$, humidity did not exceed $50 \%$, without restrictions in drinking water. The animals lived in cages of the single-tier type with a front wall made of metal mesh. They were well equipped with natural and artificial lighting.
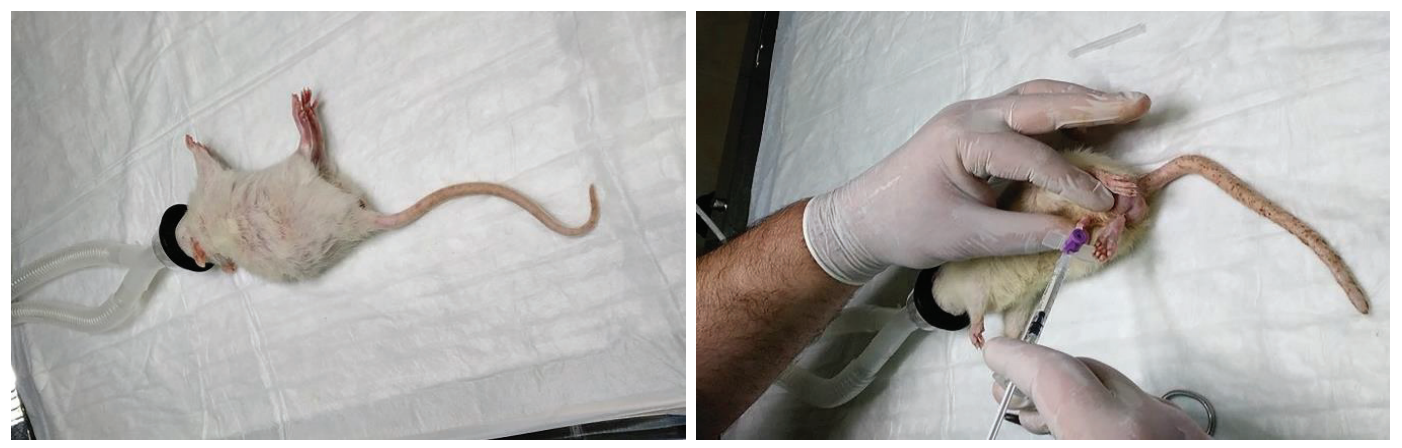

Fig. 1. Introduction of inhalation anesthesia and simulation of bacterial cystitis in rats by introduction of Escherichia coli into the bladder

Animals were removed from the experiment on the 14th day. Euthanasia was performed in accordance with bioethical standards (after previous thiopental-sodium anesthesia at the rate 
of $60 \mathrm{mg} \cdot \mathrm{kg}^{1}$ body weight of animals intraperitoneally). The collected material (bladder) was fixed for 14 days in a $10 \%$ solution of neutral formalin ( $\mathrm{pH}-7.0)$, and then carried out to paraffin blocks according to conventional methods [23]. Sections with a thickness of 5-8 $\mu \mathrm{m}$ were obtained, followed by staining with hematoxylin and eosin.

\section{Research results}

The main results of the research are presented in Table $\mathbf{1 .}$

Fig. 2 shows the bladder wall of a healthy rat with a single physiological process of desquamation.

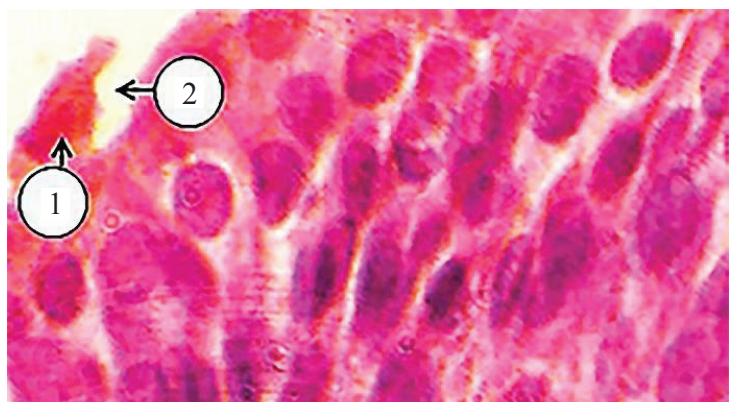

A

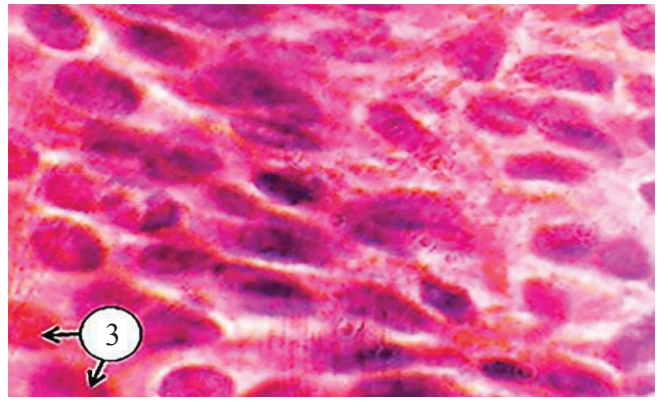

B

Fig. 2. Physiological desquamation (A) and umbrella cells in the transitional epithelium of the mucous membrane of the bladder wall of rats were normal (B). Hematoxylin and eosin staining.

Photomicrograph. Magnification: eyepiece 20, lens 40. Designation: 1 - urotheliocyte, which

will exfoliate; 2 - free area after desquamation of the cell; 3 - mononuclear umbrella cells

Table 1

Changes in bladder tissues observed during Escherichia coli infection and treatment with «Canefron ${ }^{\circledR} \mathrm{N}$ », condensed fruit juice from Vaccinium oxycoccos and «Cranberry» granules

\begin{tabular}{|c|c|c|}
\hline \multirow{2}{*}{$\begin{array}{l}\text { Group of ani- } \\
\text { mals }\end{array}$} & \multicolumn{2}{|r|}{ Examination of the bladder wall } \\
\hline & Mucous membrane & Muscle membrane \\
\hline 1 & 2 & 3 \\
\hline Healthy animals & $\begin{array}{l}\text { Loose connective tissue, which } \\
\text { contains fibrocytes, fibroblasts, } \\
\text { lymphocytes, macrophages and } \\
\text { mast cells between the bundles } \\
\text { of collagen fibers. The process } \\
\text { of single desquamation is phy- } \\
\text { siological }\end{array}$ & $\begin{array}{l}\text { Three-layer outer and inner } \\
\text { layers - longitudinal smooth } \\
\text { muscle fibers and the middle } \\
\text { layer - circular }\end{array}$ \\
\hline $\begin{array}{l}\text { Animals with } \\
\text { simulated bacte- } \\
\text { rial inflammation } \\
\text { without treatment }\end{array}$ & $\begin{array}{l}\text { Significant increase in des- } \\
\text { quamation of the transitional } \\
\text { epithelium, especially umbrella } \\
\text { cells, urotheliocytes of the } \\
\text { intermediate and basal layers. } \\
\text { In some areas it is possible } \\
\text { to note total desquamation of } \\
\text { urotheliocytes of a transitional } \\
\text { epithelium, the basal membrane } \\
\text { is exposed. There are wedge- } \\
\text { shaped ruptures of the urothe- } \\
\text { lium, which in some places reach } \\
\text { the intermediate and basal layer }\end{array}$ & $\begin{array}{l}\text { Significant edematous } \\
\text { changes, characterized by } \\
\text { an increase in the size of the } \\
\text { nuclei and enlightenment of } \\
\text { the cytoplasm. Significant } \\
\text { expansion and enlightenment } \\
\text { of the intercellular space due } \\
\text { to its edema and defibering of } \\
\text { connective tissue fibers }\end{array}$ \\
\hline
\end{tabular}

Blood vessels Outer shell 5

Constructed fibrous con- Blood vessels nective tissue with a small are normal amount of elastic fibers. At the apex and most of the anterior and posterior walls of the bladder, the outer shell is serous and consists of flat polygonal mesothelial cells with intensely stained nuclei.

Significant cellular infiltration is noted

The lumen of the arterioles is narrowed, the walls are swollen. Dilatation of venules with a thinned wall is observed 
Continuation of the Table 1

\begin{tabular}{|c|c|}
\hline 1 & 2 \\
\hline $\begin{array}{l}\text { Animals with } \\
\text { simulated bacte- } \\
\text { rial inflammation } \\
\text { after treatment } \\
\text { with the drug } \\
\text { «Canefron }{ }^{\circledR} \mathrm{N} »\end{array}$ & $\begin{array}{l}\text { Umbrella cells and cells of the } \\
\text { intermediate layer are mainly } \\
\text { subjected to desquamation. Basal } \\
\text { layer cells without changes. There } \\
\text { are shallow wedge-shaped rup- } \\
\text { tures of the urothelium, which in } \\
\text { some places reach the intermedi- } \\
\text { ate layer }\end{array}$ \\
\hline
\end{tabular}

Animals with simulated bacterial inflammation after treatment with concentrated Vaccinium oxy$\operatorname{coccos}$ fruit juice

\author{
Umbrella cells are mainly des- \\ quamated. Areas with a normal \\ urothelium are also detected

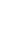

\begin{tabular}{|c|c|c|}
\hline 3 & 4 & 5 \\
\hline $\begin{array}{l}\text { In smooth myocytes there are } \\
\text { insignificant edematous chang- } \\
\text { es and expansion of intercellu- } \\
\text { lar space. In some areas of the } \\
\text { muscular membrane, a signifi- } \\
\text { cant decrease in the size of the } \\
\text { connective tissue intercellular }\end{array}$ & $\begin{array}{l}\text { There is a decrease in } \\
\text { cellular infiltration }\end{array}$ & $\begin{array}{l}\text { The lumen of } \\
\text { the arteries is } \\
\text { narrowed, the } \\
\text { wall is swollen. } \\
\text { The veins of } \\
\text { the veins are } \\
\text { thinned }\end{array}$ \\
\hline
\end{tabular}

space, which may be caused by diffuse fibrosis of the wall
There is a decrease in cellular infiltration
Histologically close to normal, but some smooth myositis is edematously altered, increased in size

The walls and lumen of the arteries and arterioles are normal. Veins are normal, in venules thinning of covers is observed

Smooth myocytes of normal shape and size, in some histopreparations it is possible to Constructed fibrous connective tissuewith a small amount of observe residual hypostasis and elastic fibers

expansion of intercellular space after treatment The intermediate and main layers with «Cranberry» of the transitional epithelium are granules histologically almost unchanged

When infected with bacteria on histological specimens there is a significant increase in desquamation of the transitional epithelium (Fig. 3).

When infected with bacteria and treatment with the drug «Canefron ${ }^{\circledR} \mathrm{N} »$ on histological preparations, desquamation of only the transitional epithelium is observed. Umbrella cells and cells of the intermediate layer are mainly subjected to desquamation (Fig. 4).

When infected with bacteria and treated with condensed juice of Vaccinium oxycoccos histologically observed desquamation of the surface layers of the transitional epithelium. Cells of the basal and intermediate layers were without changes (Fig. 5).

When infected with bacteria and treatment with granules of Vaccinium oxycoccos, the mucous membrane approaches normal (Fig. 6).

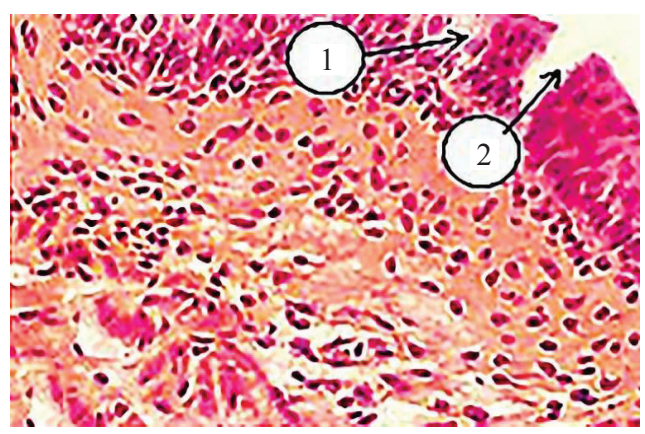

A

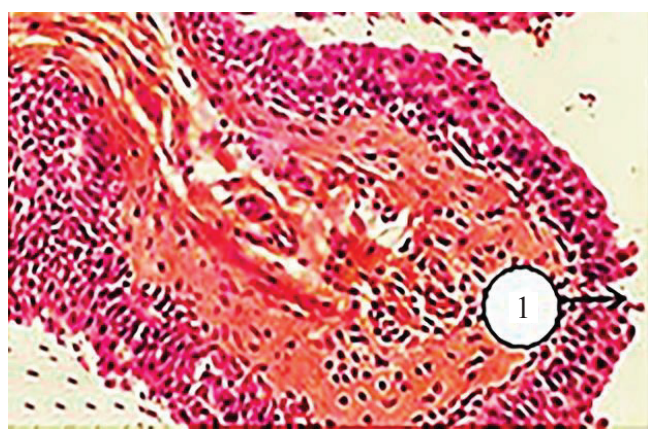

B

Fig. 3. Desquamation of all layers of the transitional epithelium with the formation of wedge-shaped gaps when infected with bacteria. Hematoxylin and eosin staining. Photomicrograph. Magnification: A - eyepiece 10, lens 20; B - eyepiece 10, lens 4. Designation: 1 - desquamation of urotheliocytes with exposure of the basement membrane; 2 - formation of wedge-shaped gaps 


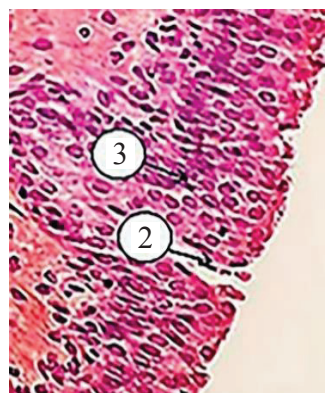

A

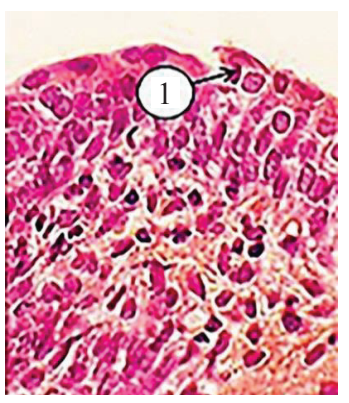

B

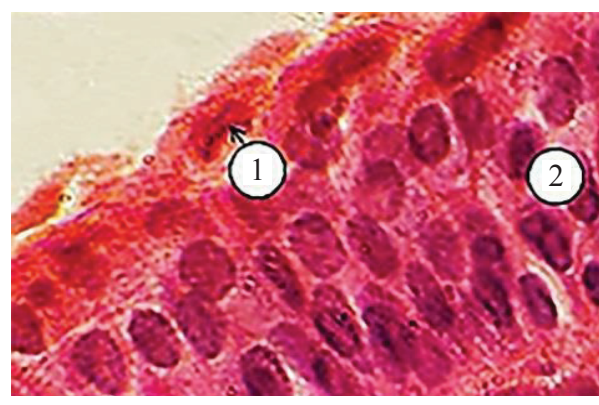

$\mathrm{C}$

Fig. 4. Histostructure of the transitional epithelium of the bladder wall when infected with bacteria and treatment with «Canefron ${ }^{\circledR} \mathrm{N} »$. Hematoxylin and eosin staining.

Microphotographs. Magnification: A, B - eyepiece 10, lens 20, C - eyepiece 20, lens 40. Designation: 1 - desquamation of umbrella cells, 2 - formation of surface wedge-shaped gaps, 3 - desquamation of cells of the intermediate layer

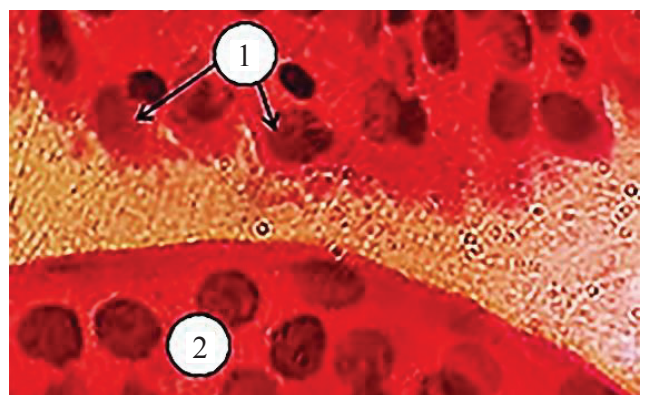

A

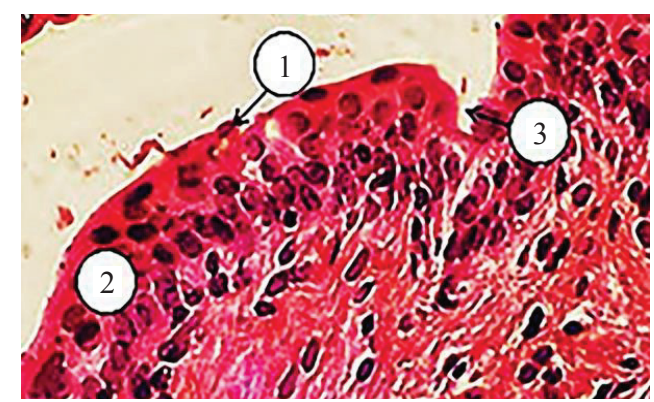

B

Fig. 5. Histostructure of the bladder wall when infected with bacteria and treatment with condensed juice Vaccinium oxycoccos fruit. Hematoxylin and eosin staining. Photomicrograph. Magnification: A - eyepiece 20, lens 40, B - eyepiece 10, lens 20. Designation: 1 - desquamation of umbrella cells, 2 - unchanged transitional epithelium, 3 - formation of superficial wedge-shaped gaps

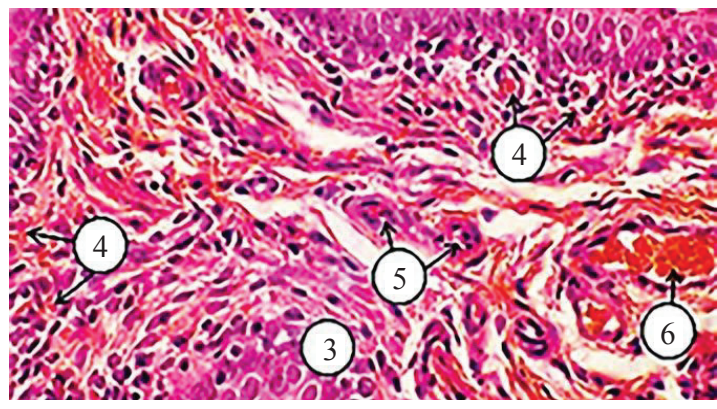

A

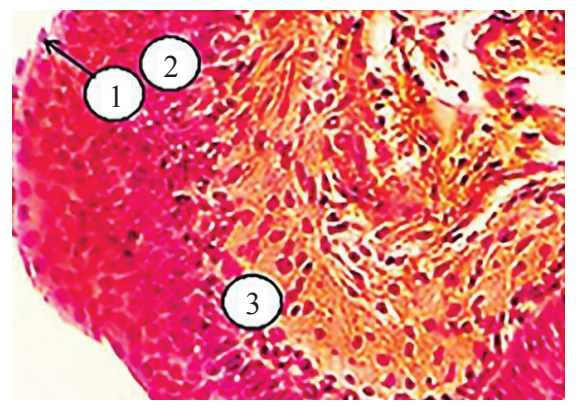

$\mathrm{B}$

Fig. 6. Histostructure of the bladder wall when infected with bacteria and treatment with granules «Cranberry». Hematoxylin and eosin staining. Photomicrograph.

Larger: A, B - eyepiece 10, lens 20. Designation: 1 - single desquamation of umbrella cells, 2 - unchanged intermediate layer, 3 - unchanged main layer, 4 - capillaries of the suburethral hemomicrocirculatory tract, 5 - arterioles, 6 - venules

\section{Discussion of the research results}

Numerous clinical studies have demonstrated statistically significant efficacy of Vaccinium oxycoccos juice in the form of concentrates, cocktails and capsules for the prevention of recurrence of urinary tract infections in women [24-26]. These facts indicate the feasibility of studying the anti-inflammatory effect of condensed juice from Vaccinium oxycoccos fruits and granules «Cranberry» in a model of bacterial cystitis in rats. When analyzing the results of the study, it was found that when 
infected with Escherichia coli bacteria on histological preparations there is a significant increase in desquamation of the transitional epithelium, edema, cell infiltration, narrowing of blood vessels. In the treatment of animals with the drug «Kanefron ${ }^{\circledR} \mathrm{N} »$ umbrella cells and cells of the intermediate layer are subjected to desquamation. Also in the transitional epithelium there are shallow wedge-shaped ruptures of the urothelium, which in some places reach the intermediate layer. When infected with bacteria and treated with condensed juice Vaccinium oxycoccos histologically observed desquamation of the surface layers of the transitional epithelium. It should be noted that along with areas of transitional epithelium, in which pathological changes are observed, areas with normal urothelium, as well as areas with superficial wedge-shaped ruptures of the urothelium are found. When infected with Escherichia coli bacteria and treatment with Vaccinium oxycoccos granules, the mucous membrane approaches normal. The transitional epithelium is three-layered with a single desquamation of umbrella cells.

In animals introduction the drug «Canefron ${ }^{\circledR} \mathrm{N} »$ in the vascular plexuses in the bladder wall there is a mosaic of histological picture: along with normal arterial vessels can be found spasmodic walls with edema. In the treatment of condensed juice with Vaccinium oxycoccos fruit in the vessels of all plexuses of the bladder wall there is a polymorphism of changes: unchanged arterial and slightly dilated and thinned venous vessels. At the same time at use of granules with condensed juice normalization of a histologic picture of vascular plexuses in a wall of a bladder is noted.

Thus, it is established that the positive effect on the tissues of the bladder wall, namely: reduction of desquamation of the superficial layers of the transitional epithelium and normalization of the histological picture of vascular plexuses in the bladder wall, after treatment of animals with condensed juice and granules of Vaccinium oxycoccos does not yield the effect of the comparison drug «Canefron ${ }^{\circledR} \mathrm{N} »$.

Study limitations. The study did not investigate the effect of the studied drugs on the blood of animals.

Prospects for further research. The obtained results confirm the prospects of conducting clinical studies of the influence of the developed drugs on the course of cystitis in humans.

\section{Conclusions}

1. It is established that the use of condensed juice from Vaccinium oxycoccos fruits or granules «Cranberry» causes a weakening of the desquamation of the surface layers of the transitional epithelium of the bladder wall, reducing edema of blood vessels and bringing the lumen of arterioles and venules to normal in rats, with simulated, the introduction of E. coli, cystitis.

2. It is established that the obtained positive effect on the tissues of the walls and blood vessels of the bladder is not inferior to the effect of the comparison drug «Canefron ${ }^{\circledR} \mathrm{N} »$.

\section{Conflict of interests}

The authors declare that they have no conflicts of interest.

\section{References}

[1] Liutikova, M. N., Botirov, E. Kh. (2015). Khimicheskii sostav i prakticheskoe primenenie iagod brusniki i kliukvy. Khimiia rastitelnogo syria, 2, 5-27. Available at: https://cyberleninka.ru/article/n/himicheskiy-sostav-i-prakticheskoe-primenenieyagod-brusniki-i-klyukvy/viewer

[2] Unifikovanyi klinichnyi protokol medychnoi dopomohy. Diahnostyka ta likuvannia infektsii sechovydilnoi systemy (2011). Available at: https://www.dec.gov.ua/wp-content/uploads/2019/11/816dod1_2.pdf

[3] Yatsiuk, K. M., Feodorovska, M. I., Kutsyk, R. V. (2018). The investigation of the cranberry (Vaccinium oxycoccos L.) concentrated juice antimicrobial activity. Farmatsevtychnyi Zhurnal, 1, 84-92. doi: http://doi.org/10.32352/0367-3057.1.17.11

[4] Davidson, E., Zimmermann, B. F., Jungfer, E., Chrubasik-Hausmann, S. (2013). Prevention of Urinary Tract Infections withVacciniumProducts. Phytotherapy Research, 28 (3), 465-470. doi: http://doi.org/10.1002/ptr.5047

[5] LaPlante, K. L., Sarkisian, S. A., Woodmansee, S., Rowley, D. C., Seeram, N. P. (2012). Effects of Cranberry Extracts on Growth and Biofilm Production of Escherichia coli and Staphylococcus species. Phytotherapy Research, 26 (9), $1371-1374$. doi: http://doi.org/10.1002/ptr.4592

[6] Kirillov, V. I., Bogdanova, N. A., Morozov, S. L. (2018). Non-antibacterial alternative measures for urinary tract infection in children. Part 1. Suppression of the microbial initiation of the inflammation. Rossiyskiy Vestnik Perinatologii i Pediatrii (Russian Bulletin of Perinatology and Pediatrics), 63 (1), 106-112. doi: http://doi.org/10.21508/1027-4065-2018-63-1-106-112 
[7] Ulrey, R. K., Barksdale, S. M., Zhou, W., van Hoek, M. L. (2014). Cranberry proanthocyanidins have anti-biofilm properties against Pseudomonas aeruginosa. BMC Complementary and Alternative Medicine, 14 (1), 414-499. doi: http:// doi.org/10.1186/1472-6882-14-499

[8] Gupta, K., Chou, M. Y., Howell, A., Wobbe, C., Grady, R., Stapleton, A. E. (2007). Cranberry Products Inhibit Adherence of P-Fimbriated Escherichia Coli to Primary Cultured Bladder and Vaginal Epithelial Cells. Journal of Urology, 177 (6), 2357-2360. doi: http://doi.org/10.1016/j.juro.2007.01.114

[9] Rane, H. S., Bernardo, S. M., Howell, A. B., Lee, S. A. (2013). Cranberry-derived proanthocyanidins prevent formation of Candida albicans biofilms in artificial urine through biofilm- and adherence-specific mechanisms. Journal of Antimicrobial Chemotherapy, 69 (2), 428-436. doi: http://doi.org/10.1093/jac/dkt398

[10] LaPlante, K. L., Sarkisian, S. A., Woodmansee, S., Rowley, D. C., Seeram, N. P. (2012). Effects of Cranberry Extracts on Growth and Biofilm Production of Escherichia coli and Staphylococcus species. Phytotherapy Research, 26 (9), $1371-1374$. doi: http://doi.org/10.1002/ptr.4592

[11] Unifikovanyi klinichnyi protokol medychnoi dopomohy. Hostryi neuskladnenyi tsystyt u zhinok (2011). Nakaz MOZ Ukrainy No. 816. 23.11.2011. Available at: http://search.ligazakon.ua/1_doc2.nsf/link1/MOZ23600.html

[12] Hryhorenko, V. M., Romashchenko, O. V., Biloholovska, V. V., Volkov, S. S. (2016). Stratehiia likuvannia neuskladnenykh infektsii nyzhnikh sechovyvidnykh shliakhiv. Novosty medytsyni y farmatsyy v Ukrayne, 11 (585), 9-14. Available at: http:// www.mif-ua.com/archive/article/43685

[13] Nastanova Yevropeiskoi asotsiatsii urolohiv iz likuvannia infektsii sechovykh shliakhiv (EAU, 2012/2013). Available at: http:// www.mif-ua.com/archive/article/36615

[14] Medved, V. I., Islamova, E. V., Kirilchuk, M. E. (2015). Ekstrakt iagod kliukvy v profilaktike i lechenii infektsii mochevyvodiaschikh putei u beremennykh. Zdorove zhenschiny, 1 (97), 36-40.Available at: http://nbuv.gov.ua/UJRN/Zdzh_2015_1_8

[15] Safronova, I. V., Goldina, I. A., Gaidul, K. V. (2015). Biologicheski aktivnye komponenty kliukvy i ikh primenenie v meditsine. Innovatsii i prodovolstvennaia bezopasnost, 1 (7), 6-18.

[16] Yatsiuk, K. M., Fedorovska, M. I., Kovalska, N. P. (2015). Zhuravlyna bolotna (Oxycoccus palustris pers.L.) yak dzherelo dlia oderzhannia likarskykh zasobiv. Fitoterapiia chasopys, 2, 26-28.

[17] Yatsyuk, K. M., Fedorovska, M. I., Barna, O. M. (2015). Granules composition and technology development based on condensed cranberry juice for urological use K. M. The Pharma Innovation Journal, 4 (8), 29-30. Available at: http://www. thepharmajournal.com/archives $/$ ?year $=2015 \&$ vol $=4 \&$ issue $=8 \&$ ArticleId $=662$

[18] Yatsiuk, K. M., Fedorovska, M. I. (2016). Pat. No. 116426 UA. Zasib dlia zastosuvannia v urolohii. MPK: A61K 9/20, A61K 36/00. No. u 201610598; declareted: 20.10.2016; published: 25.05.2017, Biul. No. 10, 4.

[19] Yatsyuk, K. M., Fedorovskaya, M. I., Marchyshyn, S. M., Budniak, L. I., Slobodianiuk, L. V. (2019). Obtaining and standardization of condensed juice from cranberries marsh fruits. Medical and Clinical Chemistry, 2, 55-60. doi: http:// doi.org/10.11603/mcch.2410-681x.2019.v.i2.10294

[20] Directive 2010/63/EU Legislation for the protection of animals used for scientific purposes. Available at: http://ec.europa.eu/ environment/chemicals/lab_animals/legislation_en.htm

[21] ARRIVE guidelines. Available at: https://www.nc3rs.org.uk/arrive-guidelines

[22] Kirpatovskiy, V. I., Mudraya, I. S., Grekov, E. A., Kabanova, I. V., Golovanov S.A., Drojjeva, V. V. et. al. (2013). Influence of the experimental metabolic syndrome on the function of the urinary bladder in rats. Ekspirimentalnaia i klinicheskaia urologiia, 1, 8-13. Available at: https://ecuro.ru/sites/default/files/ECU_8-13\%20kirpatovskiy.pdf

[23] Amdii, R. E., Al-Shukri, S. H., Kuzmin, I. V., Sorokin, N. V., Chaplitskii, E. A., Skvortsov, M. V. et. al. (2016). Use of Kanefron in treatment of acute uncomplicated cystitis in women. Urologicheskie Vedomosti, 6 (2), 16. doi: http://doi.org/10.17816/uroved6216-22

[24] Davidson, E., Zimmermann, B. F., Jungfer, E., Chrubasik-Hausmann, S. (2013). Prevention of Urinary Tract Infections withVacciniumProducts. Phytotherapy Research, 28 (3), 465-470. doi: http://doi.org/10.1002/ptr.5047

[25] Guay, D. R. P. (2009). Cranberry and Urinary Tract Infections. Drugs, 69 (7), 775-807. doi: http://doi.org/10.2165/00003495200969070-00002

[26] Howell, A. B. (2007). Bioactive compounds in cranberries and their role in prevention of urinary tract infections. Molecular Nutrition \& Food Research, 51 (6), 732-737. doi: http://doi.org/10.1002/mnfr.200700038 